\title{
The Role of Government Control on Consumer Behavior to be Environmentally Oriented
}

\author{
Dipa Mulia ${ }^{1}$ and Muchsin Saggaff Shihab ${ }^{2}$ \\ ${ }^{1}$ Universitas Mercu Buana - Jakarta \\ ${ }^{2}$ Universitas Bakrie \\ E-mail Address: \\ dipa.mulia@mercubuana.ac.id; muchsin.shihab@bakrie.ac.id
}

\begin{abstract}
Consumer orientation towards Green Products or environmentally friendly products is one of the supporting factors for business continuity (business sustainability). Consumer behavior in choosing a product is primarily determined by several things such as available product design, consumer knowledge, government control over consumers and producers. The role of the Government, Consumers and Producers together forms consumers' character in selecting the products to be consumed; therefore, the part of these three elements becomes essential to study. This study focuses on the role of government control, considering that other variables, namely consumers and producers, have been widely discussed in previous research studies. This study involved 210 respondents who live in Jakarta and surrounding areas. The selection of respondents was carried out by purposive sampling method with the criteria of respondents being groups of people who buy products for their own needs (not for resale). Data analysis was performed using Structure Equation Modeling - Partial Least Square (SEM-PLS). The results revealed that Government Control and Product Design had a direct and significant impact on consumer behavior, while consumer knowledge indirectly affected consumer behavior.
\end{abstract}

Keywords: Product Design, Government Control, Consumer Knowledge, Consumer Behavior.

\begin{abstract}
Abstrak: Orientasi konsumen terhadap Green Product merupakan salah satu faktor pendukung kesinambungan usaha. Perilaku konsumen dalam memilih produk sangat ditentukan oleh beberapa hal seperti Desain Produk, Pengetahuan Konsumen dan Kontrol Pemerintah terhadap konsumen dan produsen, oleh karenanya elemen ini menjadi sangat penting untuk diteliti. Penelitian ini menitik-beratkan kepada peran kontrol pemerintah mengingat variabel lainnya yaitu konsumen dan produsen sudah banyak dibahas dalam penelitian penelian sebelumnya. Penelitian ini melibatkan 210 responden di wilayah Jakarta dan sekitarnya. Pemilihan responden dilakukan dengan metoda purposive sampling dengan kriteria responden adalah kelompok masyarakat yang membeli produk untuk keperluannya sendiri (bukan untuk dijual kembali). Analisis data dilakukan menggunakan Structure Equation Modeling (SEM). Hasil penelitian menunjukkan bahwa Kontrol Pemerintah dan Desain Produk berpengaruh secara langsung dan signifikan terhadap Perilaku Konsumen, sedangkan Pengetahuan Konsumen berpengaruh secara tidak langsung dalam membentuk Perilaku Kosumen.
\end{abstract}


Kata Kunci: Desain Produk, Kontrol Pemerintah, Pengetahuan Konsumen, Perilaku Konsumen.

\section{INTRODUCTION}

The concept of Green Products, or environmentally friendly products, is well known by the people of Indonesia. The definition of a green product in this study is a product that does not damage the environment and does not damage the health of its users, meaning that both product content and attributes (such as packaging) do not cause damage to consumers and the environment. People who primarily act as consumers have their behavior in choosing products, including choosing Green Products. This behavior in selecting a product is also known as consumer behavior. The behavior of consumer towards Green Products can be expressed in various actions such as having a preference for Green Products over other products or promoting the use of Green Products.

A survey conducted by (Nielsen, 2014) shows the concern of the Indonesian people towards the environment. People's problem is reflected in a study that states that $64 \%$ of Indonesian consumer respondents are willing to pay more for products made by companies that care about the environment. Even $75 \%$ of respondents prefer to work in companies that are committed to sustainability. Survey results should also be reflected in consumer behavior in choosing products.

Producer's role in making design product is one of the determinants of consumer behavior in choosing products including Green Products. Facts show that there is an increase in waste from products that are not environmentally friendly from year to year, where $62 \%$ of the waste is a contribution from household waste or waste that people consume daily (Wulandari, 2020). Consumer behavior in choosing products is one of the determinants, and producers' role in providing environmentally friendly products also contributes.

Several previous studies explain the factors that are considered necessary when consumers choose to consume Green Products, including concern for the environment, product attributes, knowledge related to the environment, and subjective norms are the main factors driving buying interest (Joshi and Rahman, 2015). Specifically, regarding food products, the factors that play a role in choosing environmentally friendly food products are brand, attitude and knowledge (Suki, 2016). Consumer decisions in choosing Green Products are significantly influenced by Environmental Knowledge, Perception of Control, Environmental Attitude (Asih et al., 2020). Other researchers state that the factors that make consumers buy Green Products are Consumer Knowledge, Perceived Effectiveness and Concern (Kianpour et al., 2014). Other research shows that a marketing strategy known as Green Marketing is needed to increase interest in consuming Green Products. Aspects considered influential on Green Marketing are customer awareness and customer behavior (Ramli et al., 2020). In many countries consumers and producers aggressively pay attention to environmental concerns (Teoh and Gaur, 2018). The producer designs an environmentally friendly product because customers' demand for this type of product significantly increases. (Chaudhary, 2018). To consume environmentally friendly products has become a trend in the customer as the lifestyle even customers are willing to pay more for it (Lin et al., 2017). 
Previous research mostly observed the involvement of Producers (Design Products) and consumers as determinants of Green Product consumption. The results of this study are not accurate because there is still a gap between the results of the study and the actual situation. This research fills the gap by involving the government as Control and Policy (controller) which completes the Product Design and Customer Knowledge variables. The control role of the government, consumer society and producers is expected to build awareness and shape consumer attitudes towards Green Products. The previous research focuses on the role of consumers and producers in marketing Green Products, and this study introduces the role of government as a variable in controlling consumers and producers. The government is a party that plays a role in making regulations and policies (regulation and policy). The consumers are equipped with knowledge and information related to the environment, the products (consumer knowledge). The Producers is a party who create and market a products (Product Design). The Government, Consumer Knowledge, and Product Design built a consumer behavior (Consumer Behavior) who become more concerned with environmentally friendly products (Green Products). The purpose of this research is to take strategic steps by each party, namely the government, consumers and producers, in shaping consumer behavior that is more environmentally oriented (Green Product oriented).

The main problem raised in this study is the lack of consumer awareness in choosing products, especially for consuming Green Products. This study conveys alternatives related to the variables that need to be evaluated, namely: (1) The direct influence of Government Control on consumer behavior to be more oriented towards Green Product. (2) The influence of government control indirectly on consumer behavior to be more oriented towards Green Product. (3) The direct influence of Consumer Knowledge on consumer behavior to be more oriented towards Green Product. (4) The influence of Consumer Knowledge indirectly on consumer behavior to be more oriented to Green Product. (5) The influence of Product Design on consumer behavior to be more oriented towards Green Product.

The purpose of this research is to determine strategic steps to improve consumer behavior that is more oriented towards Green Products (friendly product environment) by evaluating the following: (1) Is there a direct and significant relationship between government control and consumer behavior that is oriented towards Green Products? (2) Does Government Control have an indirect effect on consumer behavior that is oriented towards Green Product? (3) Does Consumer Knowledge have a direct effect on Consumer Behavior which is oriented towards Green Product? (4) Is there an indirect effect of Consumer Knowledge on Consumer Behavior that is oriented towards Green Products? (5) Is there any influence of Product Design with Ko Behavior?nsumen oriented towards Green Product?

\section{THEORETICAL REVIEW}

Government, Producers, Consumers and Behavior. The literature related to consumer behavior towards environmentally friendly products (Green Products) has been widely discussed, especially relation with consumer buying interest in Green Products. This study evaluates the relationship of three main elements, namely the Government in the form of Government Control, Consumers in the form of Consumer Knowledge and Producers in the form of Product Design, and the relationship of the three in shaping consumer behavior 
more environmentally oriented.

In this study, the government control is a regulation or policy applied to consumers or producers and impacts the economy and the environment, such as rules related to product quality standardization, laws related to emission limits, and regulations related to plastic bags. Consumer knowledge in this study is the knowledge possessed by consumers related to aspects of health, the environment and the criteria for environmentally friendly products. Product Design is a manufacturer's or producer's decision in making products and marketing them. Consumer Behavior defines as the process of customer in purchasing, consuming and promoting the Green Product.

Relationship between Government Control and Consumer Behavior. Government control in the form of rules and policies made by the government is considered one of the determinants of consumer behavior oriented towards Green Products. People agree that government control has a significant effect on consumer behavior even though this influence is very much determined whether it is still allowed for people to continue to consume the product conventional or related to sanctions for using traditional products (Kianpour et al., 2014). There are not many references to the role of government control over behavior consumers. For this reason, this research was carried out as a filler research gap existing from previous research. The hypothesis that is built from this theory is

\section{H1: Government Control Affects Consumer Behavior.}

Relationship of Consumer Knowledge with Consumer Behavior. Several studies have shown that consumer knowledge is related to Green Product like benefits Green Products both in the short term and especially in the long term long shape consumer behavior. Related knowledge Green Products Becomes one of the prerequisites for forming environmentallyoriented consumer behavior (Newton et al., 2015). However, other studies have only shown an indirectly significant relationship between knowledge and behavior (Liobikiene et al., 2016). Another study states a significant and positive relationship between consumer knowledge related to the environment and consumer behaviour-oriented environment (Mohamad et al., 2014). Another study in India showed that knowledge consumers do not significantly influence consumer behavior (Kumar et al., 2017). The Studies can build the Hypotheses related to the relationship between Consumer Knowledge with Consumer Behavior.

H2: Consumer Knowledge Affects Consumer Behavior.

Product Design Relationship with Consumer Behavior. Manufacturers who already have a reputation are much easier to influence consumers in choosing products than producers who are not yet known. The green brand built by a well-known brand holder society is more trusted and more influential (Suki, 2016). Product innovation can improve consumer perceptions of Green Products, indicated by environmentally friendly product innovations or eco-friendly products (Wu and Chen, 2014). Previous research formed the following hypothesis 


\section{H3: Product Design Affects Consumer Behavior.}

In addition to the relationship between the three main elements, namely Government Control, Consumers Knowledge and Product Design on Consumer Behavior there is also a relationship between variable in the main element, namely the relationship between Government Control with Consumer Knowledge, Government Control with Product Design and Consumer Knowledge with Product Design. The relationship between independent variables allows the formation of an indirect influence between the independent and dependent variables by utilizing other independent variables as mediators.

Relationship between Government Control and Product Design. Government control related to the environment is usually contained in a regulation or environmental policies (environment regulation). Government control significantly influences product innovation, leading to product design; sometimes, the government forces manufacturers to innovate to avoid environmental damage due to economic activities (Jahanshahi and Brem, 2018). Several researchers with different results evaluated the relationship between government control and product design. Government Control is sometimes expressed positively related to innovation (Doran and Ryan, 2016) and sometimes negatively related (Borghesi et al., 2015). Research that states that there is a relationship between Government Control and Product Design provides the opportunity to build the following hypothesis

H4: Government control has an indirect effect on consumer behavior with Product Design as the mediator.

Relationship between Government Control and Consumer Knowledge. Consumer knowledge related to Green Products is obtained from various ways; one of the ways government can accelerate consumer's learning process. Consumer knowledge develops with government encouragement and regulations that trigger consumer attention, primarily if the rules are related to prohibitions accompanied by sanctions (Jiang et al., 2018). Government control is a catalyst for disseminating knowledge related to the environment and triggers the creation of new products according to existing knowledge (Wong, 2013). The research states a relationship between Government Control and Consumer Knowledge. Then an indirect relationship can be built between Government Control and Consumer Behavior with Consumer Knowledge as a mediator. The hypothesis formed is

H5: Government control affects consumer behavior indirectly by Consumer Knowledge mediator.

With the relationship between Government Control and Product Design and Government Control with knowledge Consumers, then Government Control can influence behavior consumer by using two mediators so that.

H6: Government Control influences Consumer Behavior indirectly with a mediator of Consumer Knowledge and Product Design. 
Relationship between Consumer Knowledge and Product Design. Related consumer knowledge about Green Products provide individual input to manufacturers to do innovation to the product. Innovation can create new products that meet consumer expectations that refer to knowledge environmental consumers. This has happened a lot, such as creating environmentally friendly machines due to consumer demands (Friske, and Zachary, 2018). Consumer knowledge is often considered to be significantly related to consumer behavior to be more oriented towards Green Products. This opinion is rated too simple, actually needed variable mediation to implement consumer knowledge into behavior, for example, variables trust and perceived effectiveness (Wang et al., 2019). The previous research above can form and build hypotheses

H7: Consumer Knowledge has an indirect effect on Behavior Consumers with Product Design as the mediator.

\section{METHOD}

This research is quantitative research by analyzing the relationship between the independent and dependent variables either directly or indirectly. As stated in the Literature Review and Hypotheses above, the independent variable observed in this study was Government Control, namely the rules of rules made by the government that both consumers and producers must fulfil. In this study, Government Control is from now on referred to as CONTROL. Another independent variable is Product Design which is the authority and producer initiatives in creating products and marketing them; then, in research, this Product Design is denoted as PRODUCT. The following independent variable is Consumer Knowledge, namely consumer knowledge related to friendly products and consumer knowledge about the environment. Variable This Consumer Knowledge is referred to as KNOWLEDGE. The dependent variable of concern in this study is Consumer Behavior to be more oriented towards environmentally friendly products or trends consumers to prefer Green Products. Consumer Behavior as a variable independent in this study is then given a notation, as BEHAVIOR. The relationship between independent variables and the dependent variable is either directly or indirectly described in the Research Model. 


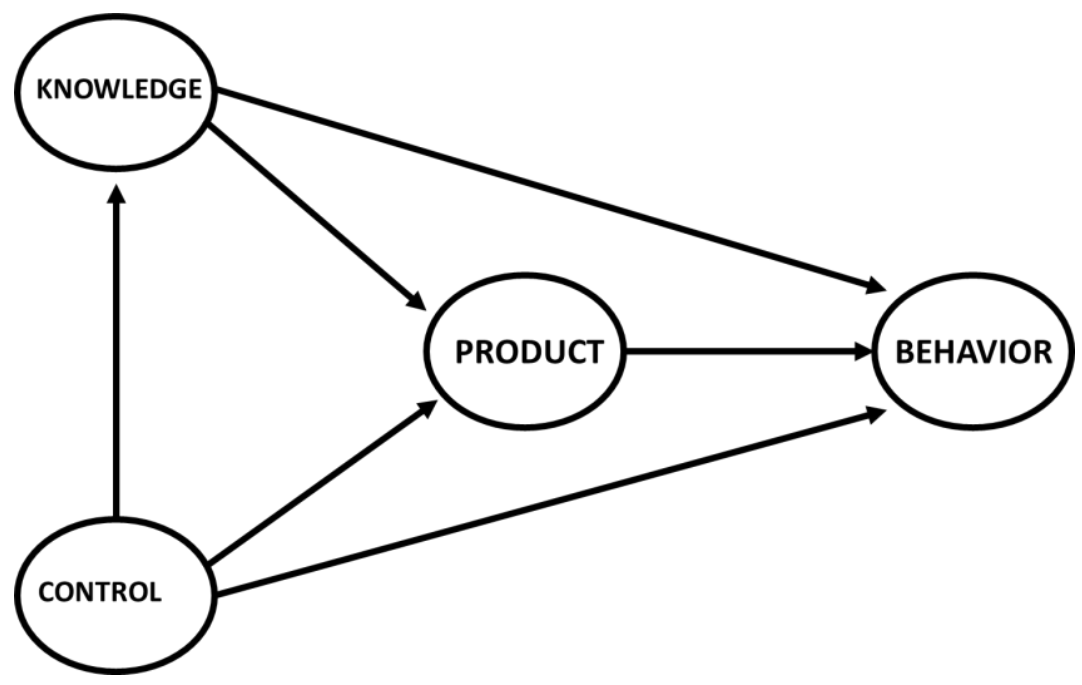

Figure 1. Research Model

Sampling and Data Collection. The data in this study were obtained through a questionnaire submitted to respondents in the JABODETABEK area (Greater Jakarta Area) by method purposive sampling or judgmental sampling. Criteria sample used are consumers who purchase a product as end-users (not for resale). The sample size in this study was 210 respondents. The size of this sample follows the established rules; namely, the minimum sample is ten times the number of indicators. This study uses 15 indicators to explain four variables latent. Respondents were asked to fill out a questionnaire related to indicators by using Likert scale 1 to 5.

Variables and Indicators. All the variables in this study are latent variables; for that reason, several indicators are needed to explain and measure the variables. Three indicators explain variable latent BEHAVIOR or Consumer Behavior with the notation (B1 Until with B3). $\mathrm{B} 1$ is that the consumer always pays attention to product labels (awareness). B2 is a customer who has a preference for Green Products (preferences). B3 is the customer always promote for consuming Green Products.

The role of each indicator in explaining the variables latent is evaluated by loading factor analysis. KNOWLEDGE latent variable is explained by five indicators (K1 to K5), while the latent PRODUCT is described by four hands (P1 to P4). Control Government or variable latent CONTROL is described by three indicators ( $\mathrm{C} 1$ to with $\mathrm{C} 3$ ). Thus this study sets 15 indicators to explain four variables latently. Descriptions for each indicator are presented in Table 1.

Each indicator as an explanatory variable latent asked for the assessment of respondents who delivered in a questionnaire. Each indicator is represented by one statement to be assessed by the respondent. Respondents were asked to rate 15 the indicator with use Likert scale of one to five. Score one means that the respondent strongly disagrees with the statement on the questionnaire while scoring five by giving the respondent if respondents strongly agree with the ideas in the questionnaire. 
The following table is an explanation of the indicators used in explaining variable latent.

Table 1. Variables and Indicators

\begin{tabular}{|c|c|c|c|}
\hline Variable & Indicator & Notation & Description \\
\hline \multirow{3}{*}{ BEHAVIOR } & Awareness & B1 & $\begin{array}{l}\text { Always pay attention to labels related } \\
\text { to Green Products }\end{array}$ \\
\hline & Preferences & B2 & Prefer to consume Green Products \\
\hline & Promoting & B3 & $\begin{array}{l}\text { Always recommend to other parties to } \\
\text { consume Green Products }\end{array}$ \\
\hline \multirow{5}{*}{ KNOWLEDGE } & $\begin{array}{l}\text { Knowing Green } \\
\text { Products }\end{array}$ & K1 & $\begin{array}{l}\text { Have sufficient knowledge related to } \\
\text { Green Product }\end{array}$ \\
\hline & $\begin{array}{l}\text { Green Product } \\
\text { as a Lifestyle }\end{array}$ & $\mathrm{K} 2$ & $\begin{array}{l}\text { Consuming Green Products is a } \\
\text { Lifestyle }\end{array}$ \\
\hline & $\begin{array}{l}\text { Knowing } \\
\text { Environment }\end{array}$ & K3 & $\begin{array}{l}\text { Realizing that the environment is } \\
\text { important for the future }\end{array}$ \\
\hline & $\begin{array}{l}\text { Ability to Select } \\
\text { a Product }\end{array}$ & K4 & $\begin{array}{l}\text { consider environmental issues when } \\
\text { purchasing products }\end{array}$ \\
\hline & Social Welfare & K5 & $\begin{array}{l}\text { Believing that the environment } \\
\text { guarantees prosperity }\end{array}$ \\
\hline \multirow{4}{*}{ PRODUCT } & Quality & $\mathrm{P} 1$ & $\begin{array}{l}\text { Believe that the quality of Green } \\
\text { Product is better }\end{array}$ \\
\hline & Price & $\mathrm{P} 2$ & $\begin{array}{l}\text { Affordable Green Product prices (not } \\
\text { expensive) }\end{array}$ \\
\hline & Availability & $\mathrm{P} 3$ & $\begin{array}{l}\text { Easy to get Green Products in the } \\
\text { market }\end{array}$ \\
\hline & Benefits & $\mathrm{P} 4$ & $\begin{array}{l}\text { Believe that consuming Green } \\
\text { Products provides benefits }\end{array}$ \\
\hline \multirow{3}{*}{ CONTROL } & Importance & $\mathrm{C} 1$ & $\begin{array}{l}\text { Government control is important to } \\
\text { promote Green Product }\end{array}$ \\
\hline & Beneficial & $\mathrm{C} 2$ & $\begin{array}{l}\text { Government control regarding green } \\
\text { products is good for consumers }\end{array}$ \\
\hline & Effective & $\mathrm{C} 3$ & $\begin{array}{l}\text { Government Control an effective tool } \\
\text { to promote Green Products }\end{array}$ \\
\hline
\end{tabular}

Data analysis was carried out using Structural Equation Model (SEM) - the SmartPLS application version 3. In addition to getting the equation structural also path analysis was performed (Path Analysis). Hypothesis testing is conducted through path analysis by evaluating the significant relationship between the variables involved.

Discussion is the interpretation of the results of data analysis which is the result of calculations statistics. The performance of the statistic calculation results is translated into a managerial corridor to take a strategic decision.

\section{RESULTS AND DISCUSSION}

Characteristics of Respondents. Respondent in this study is 210 respondents with education level of High School 47 people (22\%) and university level as many as 163 people 
(78\%). The gender composition in this study was relatively balanced, namely 98 men (47\%) and 112 women (53\%). Respondents are people who live in Jakarta and surrounding areas.

Data analysis (Statistical Test). Data analysis was carried out using the "smartpls" application version 3". Process analysis through the validity and reliability testing stages, which is then continued with analysis track. Data obtained from 210 respondents showed that not all indicators of the explanatory latent variable met the criteria. Based on Confirmatory Factor Analysis (CFA) or Outer Loading Analysis, indicator K2 does not meet the requirements. K2 has a loading factor of only 0.66 is less than 0.7 . Henceforth K2 indicator is not included in the calculations.

Other indicators are declared valid in explaining variables latent because loading factor $>0.70$. Criteria used in CFA or Outer Loading is a loading

factor indicator explaining that the variable is greater than or equal to 0.7. While the variable is declared reliable because it meets the criteria Composite Reliability (CR) $>0.7$ and Average Variance Extracted (AVE) $>0.5$ and Cronbach's Alpha > 0.6. (Hair et al., 2014). The summary of the validity and reliability test shows in Table 2.

Closeness indicator relationship in explaining latent variables can be seen from loading factor, indicators B1 to B3 explain the BEHAVIOR variable sufficiently balanced, this thing showed with value loading factor which is not much different from one other. The same thing with the KNOWLEDGE explanatory indicator, namely K1, K3, K4 and K5, with each loading factor is not much different. P1 Indikator indicator to P4 also explains the variable latentPRODUCT reasonably balanced. In another case with variable latent CONTROL, indicator $\mathrm{C} 2$ (benefits of government control for consumers) appears to be more dominant in explaining the variables latent CONTROL.

The average score is the average of 210 respondents to which indicators have been questioned. Score 1 shows that the respondents strongly do not agree with the statement on the questionnaire, while score 5 shows respondents strongly agree with the statement submitted (Likert scale 1 to 5). The indicator, which has the highest of each variable, indicates that the indicator is following consumer expectations. In contrast, the indicator with score the lowest is an indicator that is relatively less in line with respondents' expectations. 
Table 2. Validity and Reliability Test

\begin{tabular}{lllcccc}
\hline Variable & Indicator & Average Score & Loading & CR & AVE Cr Alpha \\
\hline \multirow{4}{*}{ BEHAVIOR } & B1 & 3.767 & 0.88 & & & \\
& B2 & 3.781 & 0.89 & 0.91 & 0.77 & 0.85 \\
& B3 & 3.805 & 0.87 & & & \\
& K1 & 4.505 & 0.83 & & & \\
KNOWLEDGE & K2 & 4.086 & 0.66 & & & \\
& K3 & 4.548 & 0.81 & 0.89 & 0.61 & 0.84 \\
& K4 & 4.238 & 0.81 & & & \\
& K5 & 4.486 & 0.79 & & & \\
PRODUCT & P1 & 4.362 & 0.77 & & & \\
& P2 & 3.433 & 0.75 & 0.85 & 0.58 & 0.76 \\
& P3 & 4.024 & 0.75 & & & \\
& P4 & 4.395 & 0.77 & & & \\
CONTROL & C1 & 4.433 & 0.85 & & & \\
& C2 & 4.257 & 0.91 & 0.90 & 0.75 & 0.84 \\
& C3 & 4.257 & 0.84 & & & \\
\hline
\end{tabular}

Source: processed from SmartPLS Output

The Goodness of Fit. Model fit inside Partial Least Square (PLS) expressed in several The criteria include SRMR (Standardizes Root Mean Square Residual) $<0.1$ for shows a good match. The model used in this study has an SRMR value $=0.08<0.1$. R square This study gives a figure of 0.43 means the model can explain behavior by $43 \%$ (moderate). At the same time, the ratio of chi-square to degrees of freedom (df) or (Chi-square)/df is $1.6<3$, which shows that the model is quite good.

Hypothesis Testing. The relationship between the variable independent with the dependent variable is not entirely significant-good either directly or indirectly. The relationship between the independent and dependent variables is significant if the P-values $<0.05$ or Tvalues $>1.96$. Here is the relationship between the independent variable and the dependent variable.

Table 3. Direct Relationship (Direct Effects)

\begin{tabular}{lcrl}
\hline Path & Loading & T- Value & P-Values \\
\hline KNOWLEDGE $\rightarrow$ BEHAVIOR & 0.127 & 1.410 & 0.159 \\
KNOWLEDGE $\rightarrow$ PRODUCT & 0.466 & 6.277 & 0.000 \\
PRODUCT $\rightarrow$ BEHAVIOR & 0.314 & 4.441 & 0.000 \\
CONTROL $\rightarrow$ BEHAVIOR & 0.229 & 3.031 & 0.003 \\
CONTROL $\rightarrow$ KNOWLEDGE & 0.692 & 19.851 & 0.000 \\
CONTROL $\rightarrow$ PRODUCT & 0.198 & 2.557 & 0.011 \\
\hline
\end{tabular}

Source: SmartPLS Output 
Direct influence Control Government to Consumer Behavior. Research shows that CONTROL has a significant direct effect against BEHAVIOR (P-value $=0.003<0.05$ ) with loading factor +0.229 means increased control role the government will improve consumer behavior to be more oriented towards the environment (Green Products). The relationship between the variables of Government Control on Consumer Behavior is written as CONTROL $\rightarrow$ BEHAVIOR; thus, H1: accepted.

Direct Effect of Consumer Knowledgeto Consumer Behavior. The relationship between the KNOWLEDGE variable and BEHAVIOR is expressed by significance level P-value $0.159>0.05$, meaning that the direct relationship between the Consumers Knowledge variable and Consumer Behavior variables is not significant; thus, H2: rejected.

Direct Influence of Product Design on Consumer Behavior. The Influence of Product Design (PRODUCT) on Consumer Behavior (BEHAVIOR) is significant ( $\mathrm{P}$-values $=0.00$ $<0.05)$. The loading factor +0.314 indicates that the product design improvement instantly improves consumer behavior to be more oriented towards Green Products (product environmentally friendly). The relationship between product design variables and consumer behavior can be written as follows, PRODUCT $\rightarrow$ BEHAVIOR. Hypothesis H3: accepted

A discussion of the hypothesis test of the indirect relationship among the independent variables (PRODUCT, KNOWLEDGE and CONTROL) on consumer behavior towards Green Products (BEHAVIOR) is delivered below.

Table 4. Indirect Relationship (Indirect Effects)

\begin{tabular}{llll}
\hline Path & loading & T values & P Values \\
\hline CONTROL $\rightarrow$ KNOWLEDGE $\rightarrow$ BEHAVIOR & 0.088 & 1.4 & 0.162 \\
KNOWLEDGE $\rightarrow$ PRODUCT $\rightarrow$ BEHAVIOR & 0.146 & 3.438 & 0.001 \\
CONTROL $\rightarrow$ KNOWLEDGE $\rightarrow$ PRODUCT $\rightarrow$ BEHAVIOR & 0.101 & 3.285 & 0.001 \\
CONTROL $\rightarrow$ PRODUCT $\rightarrow$ BEHAVIOR & 0.062 & 2.197 & 0.028 \\
CONTROL $\rightarrow$ KNOWLEDGE $\rightarrow$ PRODUCT & 0.323 & 5.825 & 0 \\
\hline
\end{tabular}

Source: SmartPLS Output

\section{Indirect Effect of Government Control on Consumer Behavior}

CONTROL has several indirect pathways to influence BEHAVIOR, i.e.: CONTROL $\rightarrow$ PRODUCT $\rightarrow$ BEHAVIOR with loading value +0.062 . In this path, obtained P-value $0.028<0.05$, which means CONTROL has an effect indirectly and significantly on BEHAVIOR with variable mediator PRODUCT; thus, H4 is accepted.

Another path is CONTROL $\rightarrow$ KNOWLEDGE $\rightarrow$ BEHAVIOR. The Government Control influences consumer behavior by mediating consumer knowledge (KNOWLEDGE) with a P-value of $0.16>0.05$ means that this indirect effect is not significant; thus, H5 is rejected.

Relationship path between CONTROL and BEHAVIOR with mediators consumer knowledge and product design, namely CONTROL $\rightarrow$ KNOWLEDGE $\rightarrow$ PRODUCT $\rightarrow$ BEHAVIOR. The loading factor +0.101 and P-value $0.001<0.05$ show that CONTROL 
significantly affects BEHAVIOR with the indirect path; thus, H6 is accepted.

Indirect Effect of Consumer Knowledge on Consumer Behavior. Although the knowledge variable does not affect behavior directly but indirectly can influence behavior variable with mediator product design, the line can be depicted as KNOWLEDGE $\square \rightarrow$ PRODUCT $\rightarrow$ BEHAVIOR. This path has a loading of +0.146 and a P-value of 0.001 $<0.05$, indicating that the relationship is positive and significant; thus, $\mathrm{H} 7$ is accepted.

Discussion / Managerial Implications. Research shows that not all the main elements of the independent variable directly impact consumer behavior (BEHAVIOR) significantly. Customer Knowledge (KNOWLEDGE) is the only three main elements that do not significantly affect consumer behaviour. Consumers' knowledge related to the environment does not necessarily guarantee consumers' behaviour to be more environmentally oriented. This research show that Knowledge needs to be implemented in making products that enable the formation of environmentally friendly consumer characters. The effort to make consumers more environmentally oriented by giving education and information regarding how important to maintain the environment does not significantly impact the behavior of a caring consumer society to the environment. However, Consumer Knowledge has a significant effect indirectly on Consumer Behavior by mediating product design. Providing additional knowledge about the environmental issues to the consumer creates a good understanding of the environmental issues in the customer mind and expecting to have environmentally friendly products available at the market. Manufacturers impose to create environmentally friendly products according to consumer demands. The availability of environmentally friendly products on the market creates consumer behavior that is more environmentally oriented (Green Product-oriented). Although Consumer Knowledge does not have a significant direct impact on building the Consumer Behavior, consumer knowledge improves the sustainability of consumption of Green products. The customers with good knowledge purchase the product more rationally than emotionally (Han and Hyun, 2017)

PRODUCT directly affects BEHAVIOR significantly, and even PRODUCT also mediates the KNOWLEDGE variable in influencing BEHAVIOR. The loading shows the closeness of PRODUCT and BEHAVIOR that the highest is +0.314 , relatively higher than the effect of CONTROL against BEHAVIOR directly with a value of +0.229 . The manufacturer as a maker and product marketers play a vital role in shaping the character of environment-oriented consumers.

The CONTROL variable in the study affects other variables positively and significantly. CONTROL can influence producers to produce environmentally friendly products. CONTROL can also force consumers to own knowledge related to the environment; even directly, CONTROL can also force consumers to behave in an environmentally oriented manner. Though in this study, the role of CONTROL is so vital but in other studies shows that CONTROL's role in product creation sometimes coincides characterized by a positive coefficient in the analysis (Doran and Ryan, 2016) and sometimes not unidirectional, which is characterized by a negative coefficient in the analysis (Borghesi et al., 2015). Inconsistency of government control on producers in making the product because each country has a pattern of implementation of control by law enforcement 
at different levels. When law enforcement is carried out by tight, then the relationship between government control and product design is likely to be significant and positive and vice versa if law enforcement is not too tense, then the relationship becomes negative or even insignificant. The multinational companies operating abroad are more obedient and obedient to the rules due to the sanctions imposed on them strictly by the local government (host country), so multinational companies always following local rules, including regulations related to product design (Ardito et al., 2019). In this study, CONTROL is an influential variable to BEHAVIOR either directly or indirectly. The formation of consumer behavior to be more oriented towards Green Products could be carried out by making regulations related to the use of Green Products supported with law enforcement the good one. This study states that to make consumer more environmentally oriented can be done by creating environmentally oriented products. Product design, explicitly packaging, should be prohibited from using hazardous materials and polluting the environment. Manufacturers' current initiatives to prefer paper packaging instead of plastic are efforts forcing consumers to behave in an environmentally oriented manner. The government's role in making regulations is critical because regulations can force consumers directly to environmentally oriented behavior, forcing producers to produce environmentally oriented goods. It cannot be avoided that the government's role in shaping regulations becomes essential in forming consumer character.

Research shows that all independent variables (PRODUCT, KNOWLEDGE, and CONTROL) positively and significantly affect the dependent variable (BEHAVIOR). To shape consumer behavior to be more oriented towards environmentally friendly products be done by improving performance indicators to match consumer expectations. Indicators that need attention for improvement are the lowest indicators of each latent variable, which he explained. The indicator with value (score) the low one still has room for repair performance because it does not follow respondents' expectations. For the KNOWLEDGE variable score, the lowest indicator average is K2. an indicator with a score of 4,086; however, this is invalid because of the loading factor $<0.7$. Another indicator was taken, namely K4, with a score of 4,238. K4 is consumer knowledge to choose products by considering environmental aspects. Enhancement knowledge of consumers to choose products affects the behavior for more oriented on Green Products although it is done indirectly (through mediator variable PRODUCT). Increased consumer knowledge regarding the environment and Green Products can be done with a campaign related to the benefits of maintaining the environment. Variable PRODUCT score the lowest is 3,433, which is the P2 indicator. Indicator P2 explains products in terms of prices that are considered less than expectations of consumers. Price Green Products Currently, consumers feel that they are not favorable. Price of Green Products should be set cheaper so that it has an effect to increase consumer behavior to prefer Green products. The lowest indicator of CONTROL variable score is 4,257, which is indicator C2 (Government Control beneficial to consumers) and C3 (Government Control is a tool effective). To improve consumer behavior to be more ed Green Products oriented, government policy should benefit customers. 


\section{CONCLUSION}

From the data research, several results were concluded, namely: (1) The direct effect of CONTROL on BEHAVIOR is positive and significant. (2) The effect of CONTROL on BEHAVIOR indirectly by PRODUCT mediator is positive and significant. (3) The effect of CONTROL on BEHAVIOR indirectly with the KNOWLEDGE mediator is not significant. (4) The effect of CONTROL on BEHAVIOR indirectly with KNOWLEDGE and PRODUCT mediators are positive and significant. (5) The direct effect of KNOWLEDGE on BEHAVIOR is not significant. (6) Indirect effect of KNOWLEDGE on BEHAVIOR with mediator PRODUCT is positive and significant. (7) The direct effect of PRODUCT on BEHAVIOR is positive and significant.

Suggestions for further research. Conclusion This study succeeded in introducing a new variable, namely Government Control given the notation CONTROL, which is critical in discussing Green Products and aspects of the environment. The Green Products in this research is a standard product without mentioning the type of product precisely. The conclusions obtained are a general conclusion regarding consumer behavior towards Green Products. This research model can be used to discuss consumer behavior towards certain products by specifying product types in the questionnaire. University students dominated respondents in this study, and it did not reflect the society in general. The diversity of the education level of respondents and the number of respondents should be considered for further research..

\section{REFERENCES}

Ardito, L., Messeni P.,A., Pascucci, F., Peruffo, E. (2019), “Inter Firm R\&D collaboration and green innovation value: The Role of Family Firms' involvement and the moderating effect of proximity dimension", Business Strategy and Environment, 28(1), 185-197, https:/doi.org/10.1002/bse.2248.

Asih, D., Setini, M., Soelton, M., Muna, N., Putra, I.G.C., Darma, D.C., Judiarni, J. A. (2020). "Predicting Green Product consumption using theory of planned behavior and reasoned action", Management Science Letters 10 (2020) 3367-3374.

Borghesi, S., Cainelli, G., and Mazzanti, M. (2015). "Linking Emission Trading to Environmental Innovation: Evidence from the Italian manufacturing industry", Research Policy, 44(3), 669-683. https://doi.org/10.1016/j. respol.2014.10.014.

Chaudhary, R. (2018). "Green buying behavior in India: an empirical analysis", Journal of Global Responsibility, 9(2), 179-192, doi: https://doi.org/10.1108/JGR-12-2017$\underline{0058 .}$

Doran, J., and Ryan, G. (2016). "The importance of the diverse drivers and types of environmental innovation for firm performance", Business Strategy and the Environment, 25(2), 102-119. https://doi.org/10.1002/ bse.1860.

Friske, W.M., and Zachary, M.A. (2018). "Regulation, new venture creation, and resourceadvantage theory: An analysis of the U.S. brewing industry". Entrepreneurship: Theory and Practice, https://doi.org/10.1177/1042258718760840. 
Hair, J. F., Hult, T.M., Ringle, C.M., and Sarstedt, M. (2014). A primer on partial least square structural equation modeling (PLS - SEM). Sage Publications.

Han, H., and Hyun, S. (2017), "Fostering customers' pro-environmental behavior at a museum", Journal of Sustainability Tourism, 25(9) , 1240 - 1256.

Jahanshahi, A.A.; Brem, A. (2018) Antecedents of corporate environmental commitments: The role of customers. International Journal of Environmental Research Public Health 2018, 15, 1191.

Jiang, W., Chai, H., Shao, J., and Feng, T. (2018). "Green entrepreneurial orientation for enhancing firm performance: A dynamic capability perspective", Journal of Cleaner Production, 198, 1311-1323. doi.org/10.1016/j.jclepro.2018.07.104.

Joshi, Y., Rahman, Z. (2015). "Factors Affecting Green Purchase Behaviour and Future Research Directions", International Strategic Management Review 3, pp. 128-143.

Kianpour, K., Anvari, R., Jusoh, A., Othman, M. F. (2014). "Important Motivators for Buying Green Products", Intangible Capital, Vol 10, No. 5, 2014.

Kumar, B., Manrai, A.K. and Manrai, L.A. (2017), "Purchasing behaviour for Environmentally sustainable products: a conceptual framework and empirical study", Journal of Retailing and Consumer Services, Vol. 34, pp. 1-9.

Lin, J., Lobo, A., and Leckie, C. (2017). "Green brand benefits and their influence on brand loyalty", Marketing Intelligence \& Planning, 35(3), 425-440, doi: 10.1108/MIP-092016-0174.

Liobikiene, G., Mandravickaite, J., Bernatoniene, J. (2016). "Theory of planned behavior approach to understand the green purchasing behavior in the EU: A cross-cultural study", Ecological Economics, Vol. 125, pp. 38-46

Mohamad, Z.Z., Arifin, T.R.T., Samsuri, A.S. and Munir, M.F.M.B. (2014). "Intention to visit green hotel in Malaysia: the impact of personal traits and marketing strategy", International Journal of Business and Social Science, Vol. 5 No. 7, pp. 167-173.

Newton, J.D., Tsarenko, Y., Ferraro, C., Sands, S. (2015). "Environmental Concern and Environmental Purchase Intentions: The mediating role of learning strategy", Journal of Business Research, Vol. 68, Issue 9, pp. 1974-1981.

Nielsen, (2014) Press release : Indonesian Consumer are willing to put their money where their heart is when it comes to buying goods and services from companies committed to social and environmental responsibility. (June 16, 2014).

Ramli, Y., Dudi P, Mochammad S, Swarmilah H., Tantri Y. (2020). "The Implication of Green Marketing That Influence the Customer Awareness towards Their Purchase Decision”, Mix: Jurnal Ilmiah Manajemen, Vol 10, No.3, pp 385-399.

Suki, N.M. (2016). "Green Product purchase intention: impact of green brands, attitude, and knowledge", British Food Journal Vol. 118 No. 12, 2016 pp. 2893-2910.

Teoh, C. W., and Gaur, S. S. (2018). "Environmental concern: an issue for poor or rich", Management of Environmental Quality": Vol. 30 No. 1, pp. 227-242.

Wang, H., Ma, B., Bai, R (2019)." How Does Green Product Knowledge Effectively Promote Green Purchase Intention?", Sustainability, doi:10.3390/ su11041193.

Wong, S. K. S. (2013). Environmental requirements, knowledge sharing and green innovation: Empirical evidence from the electronics industry in China. Business Strategy and the Environment, 22(5), 321-338. https://doi.org/10.1002/bse.1746. 
Wu, S., Chen, Y. (2014). The Impact of Green Marketing and Perceived Innovation on Purchase Intention for Green Products. International Journal of Marketing Studies, 6(5), 81-101.

Wulandari, R., (2020), "Perlu Bersegera untuk Kurangi Produksi dan Sampah Rumah Tangga”, Mongabay: Situs Berita Lingkungan 9 September 2020. 